\title{
Development of semi-integrated solar street lamp for rural area
}

\author{
Tomy Abuzairi ${ }^{1, *}$, Kresna Devara ${ }^{1}$, Ananta Rezky ${ }^{1}$, Andrew Bastian ${ }^{1}$, Wing Wira A.R. ${ }^{1}$, and Arief Udhiarto $^{1}$ \\ ${ }^{1}$ Department of Electrical Engineering, Faculty of Engineering, Universitas Indonesia, Kampus Baru UI Depok 16424, Indonesia
}

\begin{abstract}
A solar street lamp is a lamp technology that utilizes solar cell to obtain electrical energy during the daylight hour by solar radiation and then use the electrical energy to provide light at night. Semiintegrated lamp tries to overcome complicated installation and expensive price of normally solar street lamp. Semi-integrated solar street lamp only integrated solar cell, controller, and battery, while lamp is separated using cable. This configuration makes semi-integrated lamp cheaper and easier for installation that is suitable for rural area. Therefore, in this paper we develop semi-integrated type of solar street lamp. The illumination of semi-integrated lamp was measured using lux meter. The power of the lamp was calculated to meet the energy needs for 12 hours. The results show that the semi-integrated solar street lamp with low power LED $\sim 2 \mathrm{~W}$ has been successfully developed. The solar lamp can be automatically turned on for around 12 hours, from 5:50 PM to 5:31 AM (UTC+7). The illumination average of the lamp is 17.42 lux with 6.97 lux deviation. The measurement result of illumination shows that the solar street lamp has maximum distance of more than $140 \mathrm{~cm}$ with $230 \mathrm{~cm}$ high of lamp.
\end{abstract}

\section{Introduction}

Street lamp is a necessary part of every part of the street, with a primary function is to provide comfort to the driver and pedestrian. Street lamp also has a security function that is to prevent accidents and criminality. On the other hand, from environmental and economical perspectives, solar street lamp is better than the traditional street lamp, since the traditional technology uses far more energy during its operational life [1], [2].

Solar street lamp is a lamp that utilizes solar cell to obtain electrical energy during the daylight hour by solar radiation and then stored in the battery [3], [4]. At night, the energy saved in the battery is used to provide light on the street. Generally, there are two types of solar street lamps: (a) unintegrated lamp; (b) fully-integrated lamp, as shown in Figure 1. Unintegrated lamp is a lamp which are each component, i.e. lamp, solar cell, controller, and battery, separate from each other, as shown in Figure 1(a). However, the lack of this type of solar street lamp is in need of a complicated installation. Different from unintegrated lamp, fully-integrated lamp has integrated all the components of each lamp, as shown in Figure 1(b). The fully-integrated lamp causes easier installation, although the component price of this type is expensive [5].

Semi-integrated lamp (Figure 1c) tries to overcome both problems, that is expensive and complicated installation. Semi-integrated solar street lamp only integrated solar cell, controller, and battery, while lamp is separated using cable. This configuration makes semiintegrated lamp cheaper and easier for installation that is suitable for rural area.

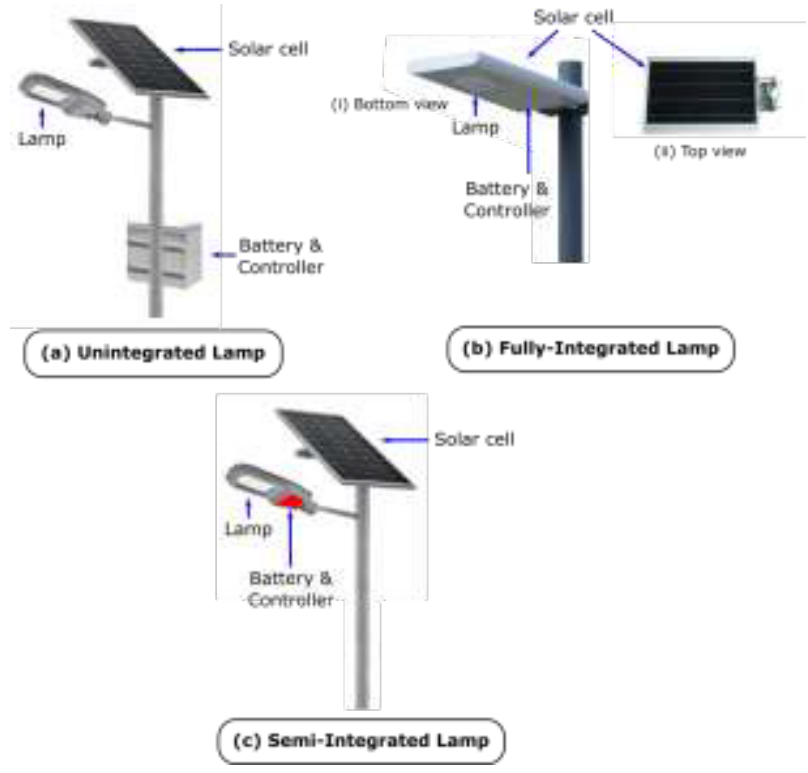

Fig. 1. Three different type of solar street lamps: (a) unintegrated lamp; (b) fully-integrated lamp; and (c) semiintegrated lamp.

Therefore, in this paper we develop new type solar street lamp, namely semi-integrated type of solar street lamp. For the measurement of the solar street lamp, the illumination of lamp was measured using lux meter. Furthermore, the power of solar street lamp was calculated to meet the energy needs of the lamp for 12 hours.

\footnotetext{
Corresponding author: tomy@ee.ui.ac.id
} 

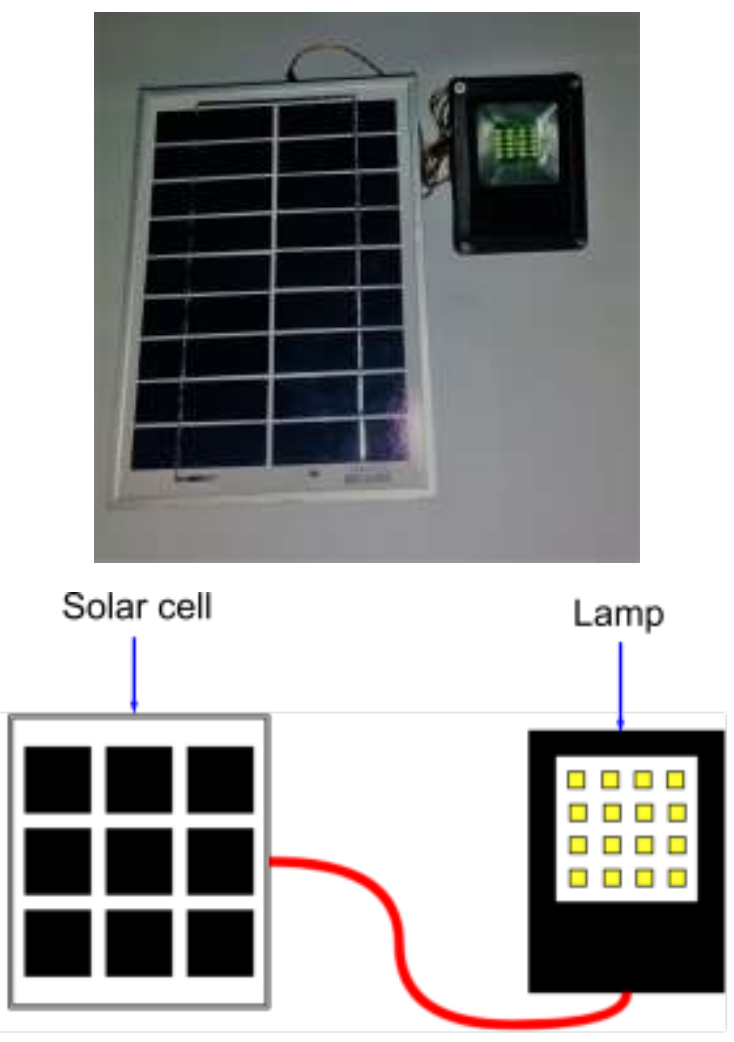

Fig. 2. Semi-integrated solar street lamp from top view.
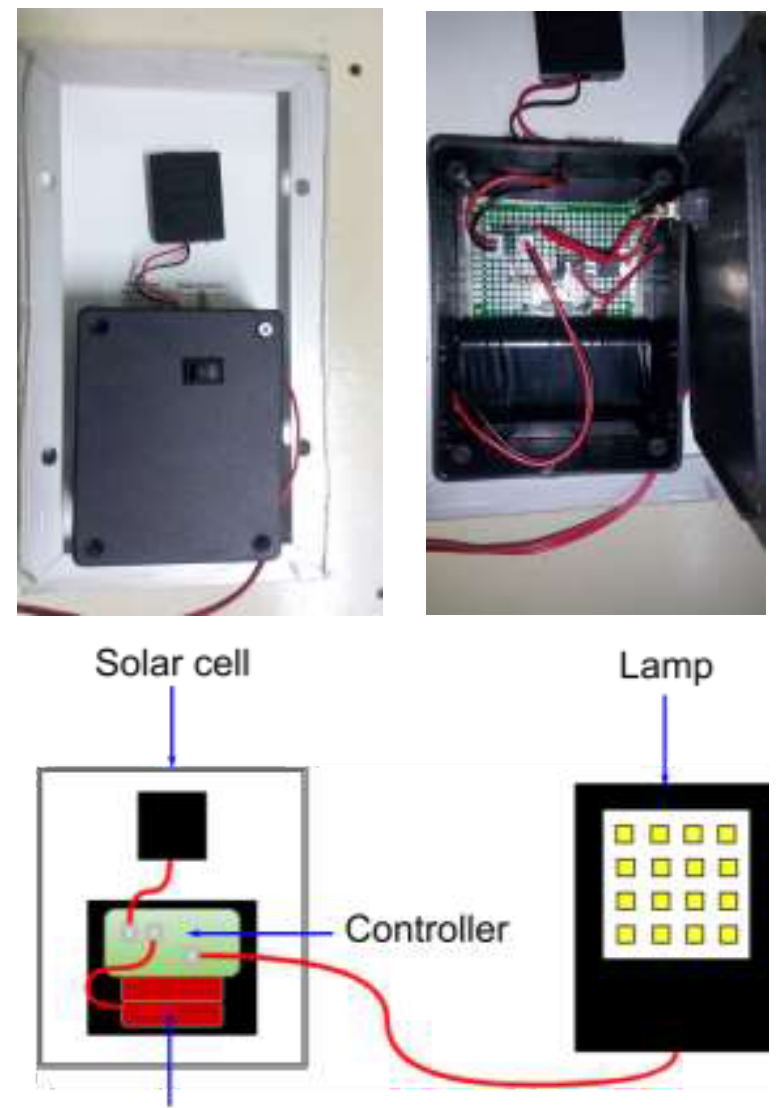

Battery

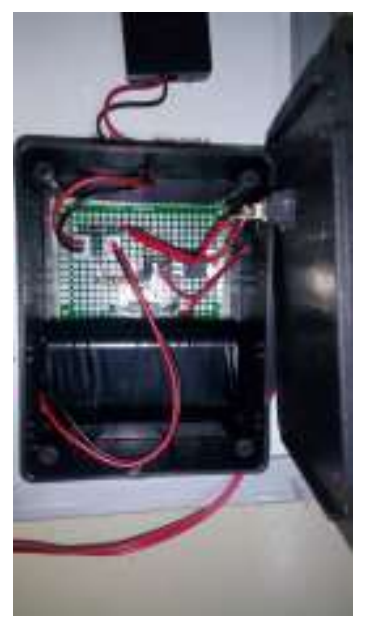

Fig. 3. Semi-integrated solar street lamp from bottom view

\section{Design of semi-integrated solar street lamp}

Design of semi-integrated solar lamp is different from normally solar street lamp. The normally solar street lamp is separate each component, such as lamp, solar cell, controller, and battery. However, this solar street lamp integrates some components, i.e. solar cell, controller, and battery, while lamp is separated using cable, as shown in Figures 2 and 3.

Figure 2 shows top view of semi-integrated solar street lamp. The lamp and the solar cell are connected to a long cable about 1-3 meters, so the lamp can be placed far from solar cell. For the lamp, this design used 10 pieces of LED SMD 2835 [6]. The LED is stored in waterproof storage to protect from the rain and connected to solar cell through battery.

Figure 3 shows bottom view of semi-integrated solar street lamp. This design has integrated only solar cell, controller, and battery, so this solar lamp can be easily installed on the lamp pole. Controller circuit will be connected to battery and solar cell through cable. The lamp controller will control the flow of current, when the battery is charged and the lamp is turned on. Furthermore, there is a manual electric switch to turn-off the solar lamp when it is not used or stored for long time.

\section{Working principle of semi-integrated solar street lamp}

The basic working principle of this solar street lamp is that the lamp will automatically turn on or turn off, as lighting in its surrounding of lamp changed. When there is enough light in the morning to afternoon, solar lamp will turn off and solar cell will charge the battery. In the night, the lamp will turn on automatically from the energy stored in the battery.

The detail working principle of the solar street lamp is illustrated in Figure 4. The system is mainly composed of six parts, i.e. solar cell, protecting circuit, battery built-in battery management system (BMS), control circuit, LED driving circuit, and LED lamp. Solar cell in this lamp is utilized to absorb solar radiation and convert it to electricity [7], [8]. Based on solar cell efficiency table, the highest crystalline Si solar cell is $27.6 \%$ [9].

In this design, the lamp used $5 \mathrm{Wp}$ (Watt peak) polycrystalline silicone solar cell with voltage at maximum power $(\mathrm{Vmp})$ of $8.93 \mathrm{~V}$ and current at maximum power (Imp) of $0.56 \mathrm{~A}$. Protecting circuit is applied to protect the reverse current from battery to solar cell. Furthermore, 7.4 Volt $3300 \mathrm{mAh}$ battery is used to light for $\sim 12$ hours at night with $162 \mathrm{~mA}$ maximum current supplied. BMS is utilized to control charging current from solar cell. Control circuit is used as controller of LED lamp to turn off or turn on in the proper conditions. 


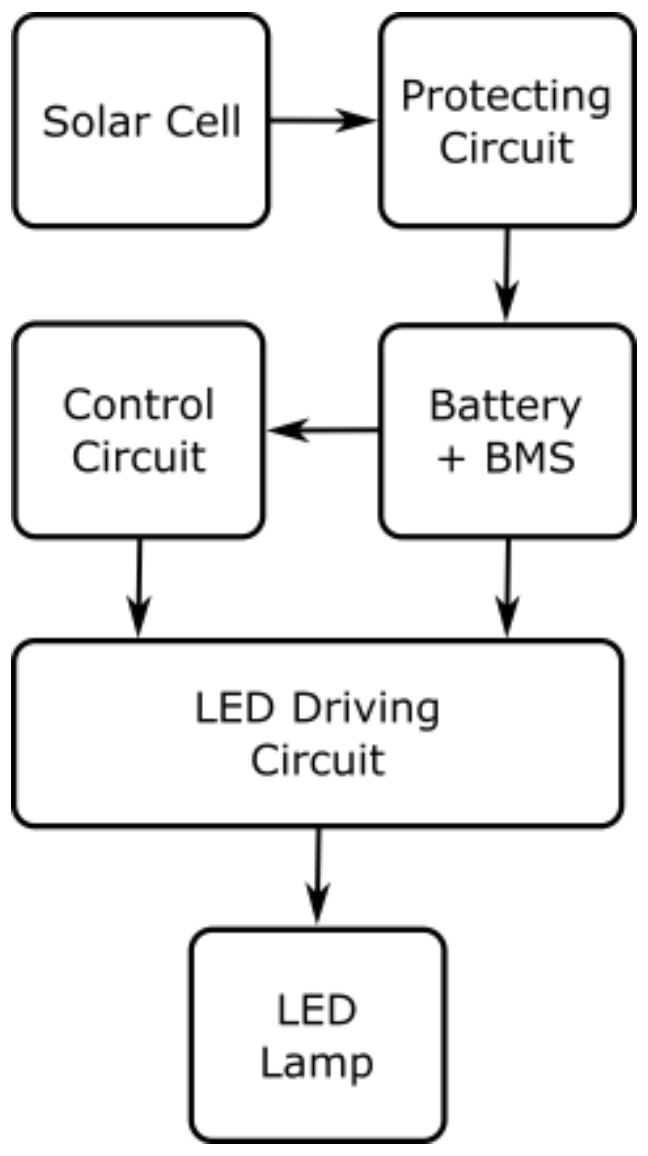

Fig. 4. Flow diagram of working principle of solar street lamp.

Figure 5 depicts the controller circuit of semiintegrated solar street lamp. To control the current of the solar cell to the lamp, the positive pole of solar cell is connected to the resistor (R2) and to the base of BJT. The transistor BJT will turn on when the solar cell voltage drops or when there is no solar radiation. This condition will also cause the gate voltage in MOSFET become active and current can flow from battery to the LED lamp and resistor (R3).

Nevertheless, when there is solar radiation, voltage on solar cell will rise and then NPN BJT will turn off, due to the drop voltage in the gate MOSFET. For this design, we add MOSFET to add stability of the circuit [10]. A diode (D1) is utilized to protect the reverse current from battery to solar cell. Switch is used to manually turn-off the lamp. If the switch is on and MOSFET is active the lamp will be turned on. Meanwhile, if the switch is turned off, even the MOSFET is active, the LED lamp will not be turned on.

\section{Experiment and Results}

The solar street lamp consists of 10 pieces of LED that connected in 2 series and 5 parallel, as shown in Figure 6. This LED lamp configuration is designed to have minimum voltage of 6 Volt and minimum current of 200 $\mathrm{mA}$. Through these measurements, the power needed to turn on the lamp is:

$$
\mathrm{P}_{\text {in }}=\mathrm{V} \times \mathrm{I}=6 \mathrm{~V} \times 200 \mathrm{~mA}=1.20 \mathrm{Watt}
$$

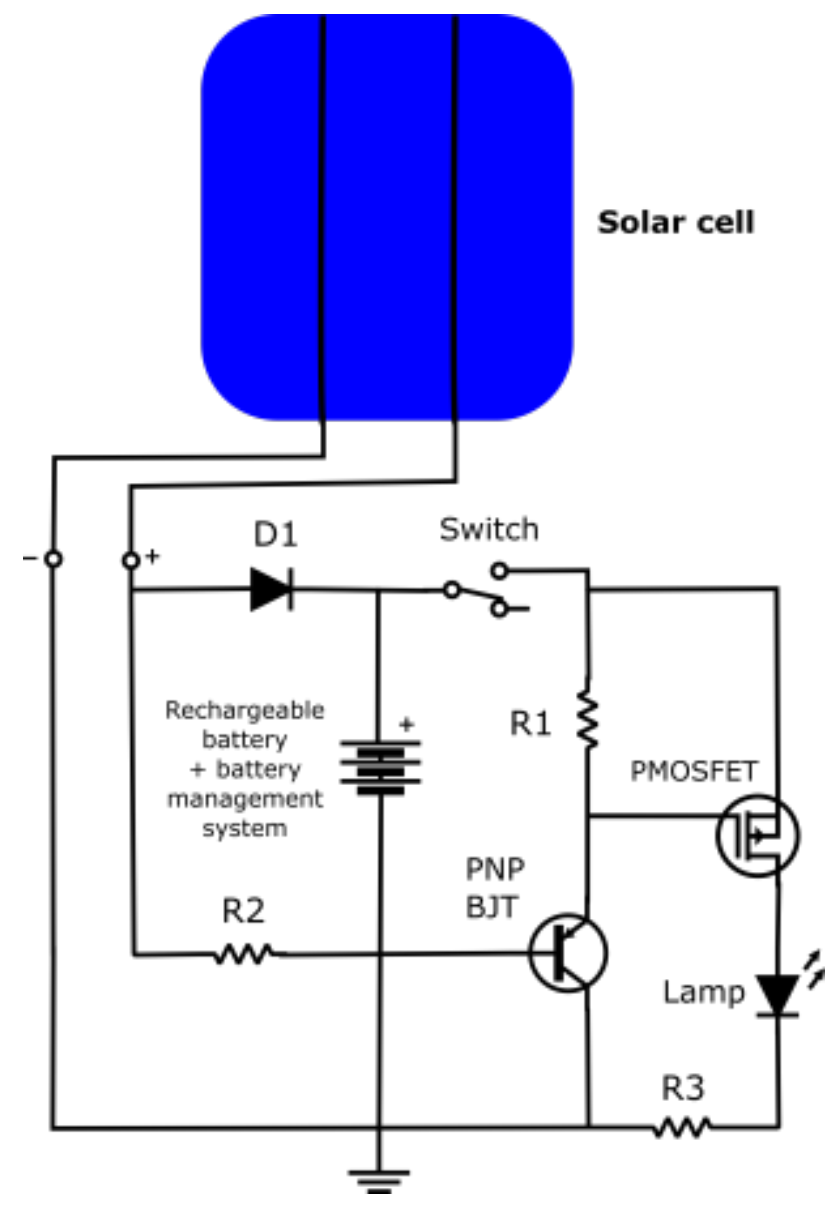

(a)

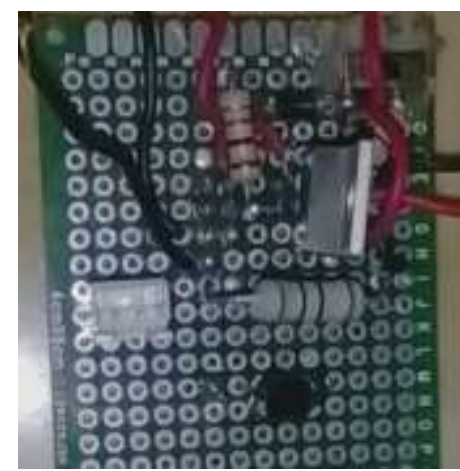

(b)

Fig. 5. Circuit of semi-integrated solar street lamp: (a) schematic and (b) photograph.

Solar street lamp generally turns on around 12 hours. Therefore, if we assume that the solar street lamp will turn on for 12 hours in the night, therefore the power needed is 12 hour times 1.2 Watt or equal to 14.4 Watt hour. Whereas, average effective time of the solar energy that will be absorb by the solar cell is 5 hours. Therefore, $5 \mathrm{Wp}$ solar cell will generate 25 Watt hour average energy per day. This energy is enough to supply solar street lamp for more than 12 hours. In the experiment, the lamp can be automatically turned on for around 12 hours, from 5:50 PM to 5:31 AM (UTC+7). 


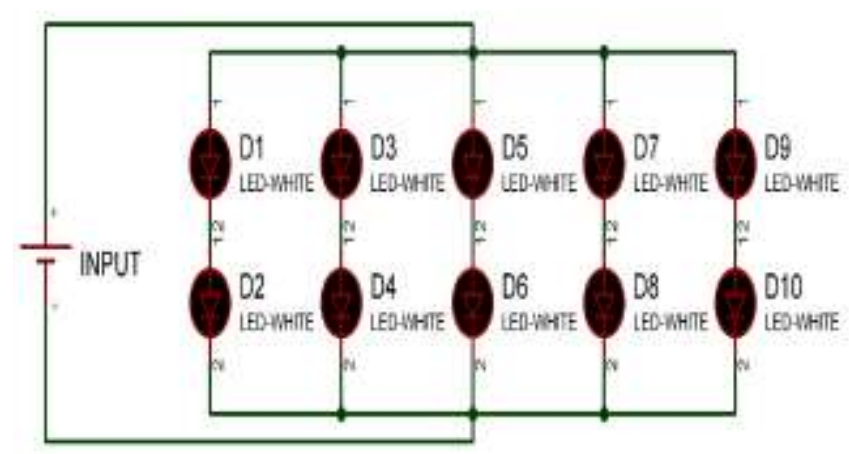

(a)

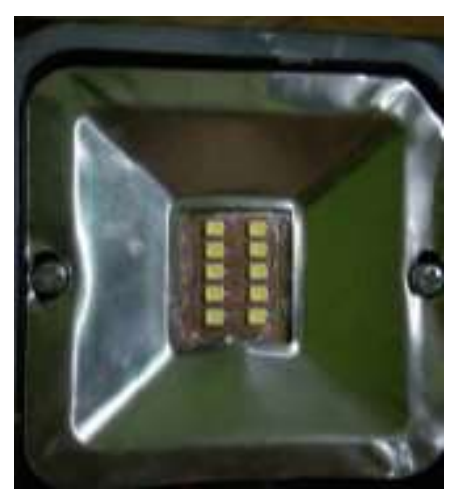

(b)

Fig. 6. Circuit of LED Lamp in the solar street lamp: (a) schematic and (b) photograph.

The load calculation is conducted by measuring the current and the voltage drop on the SMD LED lamp. The voltage of lamp is 6.03 Volt and current flowing of lamp is 0.18 Ampere. Therefore, the efficiency of solar street lamp is $92.9 \%$, as the following calculation:

$$
\begin{gathered}
\eta=\frac{P_{\text {out }}}{P_{\text {in }}} \times 100 \% \\
-\frac{1.12 \text { Watt }}{1.20 \text { Watt }} \times 100 \%-92.9 \%
\end{gathered}
$$

From economical point of view, this semi-integrated solar street lamp is cheap. Total of component price for developing this semi-integrated solar street lamp is about 25 USD. Furthermore, the semi-integrated design has integrated only solar cell, controller, and battery, and separate the LED lamp with 3-meter cable. This is made the semi-integrated solar street lamp can be easily installed on the lamp pole. Therefore, the semiintegrated type lamp is developed to meet the cheaper price and the easier installation, that is suitable for rural area.

The intensity of the solar lamp is measured in the dark room (no light) with scheme like show in Figure 7(a). There are 12 measurement point consisting of 3 rows and 4 columns. Each columns and rows is separated for $70 \mathrm{~cm}$. The lamp placed above the second column of the second row with height of $230 \mathrm{~cm}$ from the point. Lux meter placed $100 \mathrm{~cm}$ above the ground point.

Figure 7(b) shows the result of the illumination of semi-integrated solar lamp. The second column of the second row has the highest lux, because the lamp is place above it. The illumination dropped to $\sim 21.82$ lux, after $70 \mathrm{~cm}$ distance. Average illumination of this lamp is 17.42 lux with a deviation of 6.97 lux.

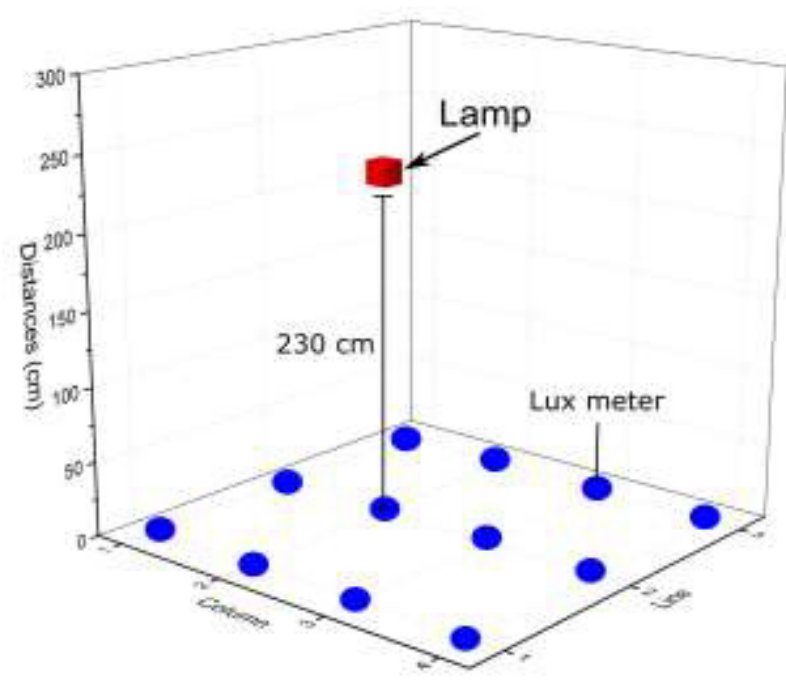

(a)

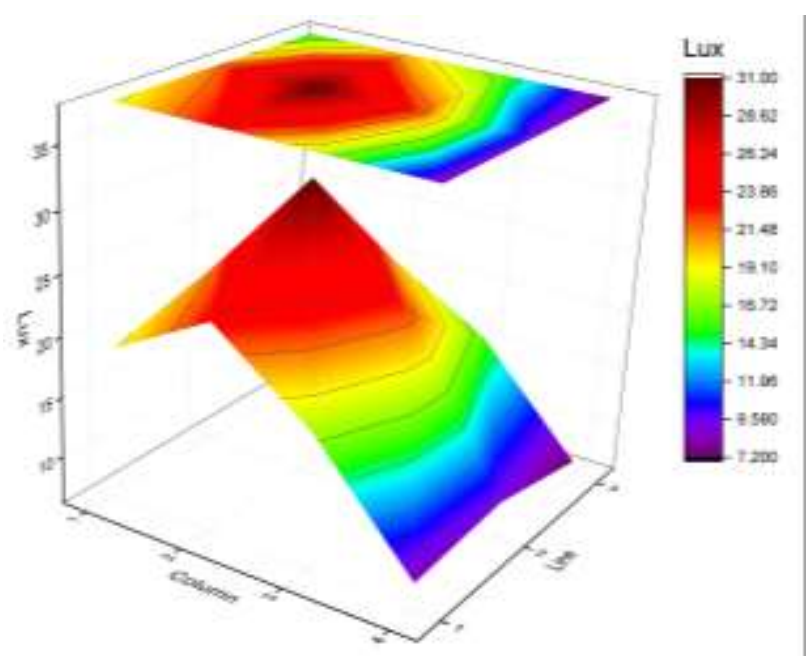

(b)

Fig. 7. (a) Measurement position of solar street lamp. (b) Illumination measurement on 12 spots.

\section{Conclusions}

Semi-integrated solar street lamp with low power LED $1.20 \mathrm{~W}$ has been successfully developed. The semiintegrated type lamp is chosen because the price is cheaper and the installation is easier, that is suitable for 
rural area. The lamp can be automatically turned on for around 12 hours, from 5:50 PM to 5:31 AM (UTC+7). The level of illumination had been tested and show the average illumination of 17.42 lux with 6.97 lux deviation. Moreover, the result shows that the solar street lamp has illumination range of more than $140 \mathrm{~cm}$ with $230 \mathrm{~cm}$ high of lamp.

This work has been supported by PITTA (No. 2382/UN2.R3.1/HKP.05.00/2018) Research Grant 2018 from Universitas Indonesia.

\section{References}

1. S. Tannous, R. Manneh, H. Harajli, and H. El Zakhem, J. Clean. Prod., vol. 186, pp. 963-977 (2018)

2. D. Campisi, S. Gitto, and D. Morea, J. Clean. Prod., vol. 175, pp. 190-198 (2018)

3. W. Yongqing, H. Chuncheng, Z. Suoliang, H. Yali, and W. Hong, ICEET'09, vol. 1, pp. 90-93 (2009)

4. C. G. Chen, U.S. Patent No. D532,141. 14, (2006)

5. T. Abuzairi, R. F. R. Saputro, and F. Nugraha, SNaPP, vol. 7, no. 1 (2017)

6. Gorgeus Group, "SMD LED Comparison," 2017. [Online]. Available: www.saving-star.com/smd-ledcomparison/. [Accessed: 07-Sep-2017]

7. T. Abuzairi and N. R. Poespawati, Advanced Materials Research, vol. 896, pp. 455-458 (2014)

8. M. A. Green, Solar cells: operating principles, technology, and system applications (Englewood Cliffs, NJ, Prentice-Hall, Inc., 1982)

9. M. A. Green, K. Emery, Y. Hishikawa, W. Warta, and E. D. Dunlop, Prog. Photovolt. Res. Appl., vol. 23, no. 1, pp. 1-9 (2015)

10. I. Yoshida, T. Okabe, M. Katsueda, S. Ochi, and M. Nagata, IEEE Trans. Electron Devices, vol. 27, no. 2, pp. 395-398 (1980) 